\title{
Fibrosis as a result of polyhexamethylene guanide exposure in cultured Statens Seruminstitut Rabbit Cornea (SIRC) cells
}

\author{
Handule Lee ${ }^{1}$, Juyoung Park ${ }^{1}$, Kwangsik Park ${ }^{1, *}$ \\ ${ }^{1}$ College of Pharmacy, Dongduk Women's University, Seoul 02748, Korea \\ *Correspondence: kspark@dongduk.ac.kr
}

Received: February, 8, 2021 Accepted: April, 29, 2021

\begin{abstract}
Previous research studies on the toxicity of polyhexamethylene guanidine (PHMG) as a humidifier disinfectant majorly focused on lung fibrosis. Considering that disinfectants in humidifiers are released in aerosol form, the eyes are directly exposed and highly vulnerable to the detrimental effects of the PHMG. Therefore, in the present study we investigated the adverse effects of PHMG on the eyes; considering fibrosis as a manifestation of PHMG toxicity in the eye, we evaluated fibrosis-related biomarkers in cultured Statens Seruminstitut Rabbit Cornea (SIRC) cells. Cell viability was measured using 3-(4,5-dimethylthiazol-2-yl)-2, 5-diphenyltetrazolium bromide (MTT) assay, fibrosis-related biomarkers were evaluated through polymerase chain reaction (PCR) and immunoblotting, and oxidative stress was evaluated using $2^{\prime}, 7^{\prime}$-dichlorodihydrofluorescein diacetate $\left(\mathrm{H}_{2} \mathrm{DCFDA}\right)$. Polyhexamethylene guanidine showed cytotoxicity in a time and concentration-dependent manner. Fibrosis related biomarkers including transforming growth factor- $\beta$ (TGF$\beta$ ), $\alpha$-smooth muscle actin ( $\alpha$-SMA), matrix metalloproteinase (MMP), tissue inhibitor of metalloproteinase (TIMP) and hemeoxygenase-1 (HO-1) increased in both gene and protein levels. Oxidative stress also increased in the PHMG-treated cultured cells. The findings of the present study suggest that PHMG could cause toxicity in the eye as manifested by fibrosis.
\end{abstract}

Keywords: $\alpha$-SMA, TGF- $\beta$, MMP, TIMP, Eye fibrosis, Polyhexamethylene guanidine (PHMG)

\section{Introduction}

After several typical pulmonary injury cases among pregnant women were reported in Korea in April 2011, a series of case studies revealed the use of humidifier disinfectants (HDs) as a potential risk factor [1-3]. HDs are chemicals that are added to the humidifier water tank to prevent the growth of microorganisms. About 20 products were in the Korean market at that time. According to a nationwide online survey, there were approximately 3.5 to 4.0 million users of HDs, and approximately $56 \%$ of the online responders were suspected worried about having respiratory diseases. Health conditions that were reported among people exposed to HDs included asthma, pneumonia, bronchitis, rhinitis, atopic dermatitis, headaches, eye disease, kidney ailments, and liver disease [4,5]. Recently, the effects of early-life exposure to HDs on lung function in children was also investigated; a trend similar to the previous studies was observed where the predicted forced expiratory volume in 1 second (FEV1) and forced vital capacity (FVC) were significantly lower in the HDs exposed group than in the control group [6].

Based on a survey of HDs products in the market, the main active ingredients were listed as polyhexamethylene guanidine (PHMG), oligo (2-(2-ethoxy) ethoxyethyl guanidinium (PGH), and a mixture of chloromethylisothiazolinone (CMIT) and methylisothiazolinone (MIT). Similar to previous studies, the survey results revealed PHMG as the highest risk factor for respiratory diseases [1,2,8]. Intratracheal instillation of PHMG into C57BL/6 mice induced severe lung inflammation manifested by the infiltration of mononuclear cells and neutrophils, and increased production of interleukin6 (IL-6), tumor necrosis factor- $\alpha$ (TNF- $\alpha$ ), chemokine (C-C motif) ligand 2 (CCL2) and chemokine (C-X-C motif) ligand 1 (CXCL1). The inflammatory responses in the lungs gradually increased until 28 days after PHMG exposure. High rates of collagen deposition and transforming growth factor-beta 1 (TGF- $\beta 1$ ) production as indicators of fibrosis were also observed in the PHMG exposed animals. The pathological changes in the PHMG treated groups were similar to those observed in HD exposure associated patients [9- 11]. When mice were exposed to $1.03 \mathrm{mg} / \mathrm{m}^{3} \mathrm{PHMG}$ through aerosol inhalation for 3 weeks or 3 weeks followed by other 3 weeks recovery, TGF- $\beta 1$ and extracellular matrix (ECM) remodeling markers were up-regulated and these parameters were aggravated after 3 weeks recovery. Extensive collagen deposition was observed in the peri-bronchiolar and interstitial areas in the PHMG exposed lungs [12]. In rats, nanometer size PHMG aerosol particles 
induced pulmonary inflammation and fibrosis manifested by inflammatory cytokines and fibronectin mRNA increase, as well as histological changes [13].

In addition to the respiratory system, the skin and eye are also highly vulnerable to the PHMG detrimental effects as suggested by an epidemiological survey [5]. However, so far, there are limited research studies on PHMG effects on the skin and eye. Eye irritation and fibrosis are the most likely manifestations of PHMG toxicity on the eye. Previously, PHMG toxicity on the eye was investigated through an eye irritation test in a tissue model of the reconstructed human cornea-like epithelium, however, there is no eye fibrosis-related study so far [14]. In this study, we investigated fibrosis as a manifestation of PHMG toxicity in the eye; we evaluated inflammatory responses and fibrosis-related biomarkers including TGF- $\beta 1$, TNF- $\alpha$, tissue inhibitors of metalloproteinases (TIMPs), matrix metalloproteinases (MMPs), and $\alpha$-smooth muscle actin ( $\alpha$-SMA).

\section{Materials and Methods Materials}

Polyhexamethylene guanidine hydrochloride (CAS No.57028-96-3) in white powder form at room temperature was provided by Dr. Y. Zheng, Qingdao University (Qingdao, China). The active ingredient was known to be $95 \%$, and PEG-6000 (CAS No. 25322-68-3) was approximately $5 \%$. Other reagents used in this study including culture media, $2^{\prime}, 7^{\prime}-$ dichlorofluorescin diacetate ( $\mathrm{H}_{2}$ DCFDA), and 3-(4,5-dimethylthiazol-2-yl)-2,5-diphenyltetrazolium bromide (MTT) were high quality products used for cellular and molecular biology study.

\section{Methods \\ Cell culture}

Statens Seruminstitut Rabbit Cornea (SIRC, ATCC® CCL-60 ${ }^{\mathrm{TM}}$ ) cells, cell lines which are derived from rabbit cornea and used for eye irritation test in OECD Test guideline 491, were supplied by the American Type Culture Collection (ATCC. Manassas, VA, USA). SIRC cells were cultured in Dulbecco's Modified Eagle Medium (DMEM) (Gibco, MA, USA) containing $10 \%$ heat-inactivated fetal bovine serum (Hyclone, MA, USA), $1 \%$ penicillin and streptomycin (1000 U/mL penicillin and $100 \mu \mathrm{g} / \mathrm{mL}$ streptomycin) at $37^{\circ} \mathrm{C}$ with $5 \% \mathrm{CO}_{2}$ condition. Cells were seeded as in numbers of $5 \times 105 \mathrm{cells} / \mathrm{mL}$ in each well of 96 -well plate, and pre-incubated for $24 \mathrm{~h}$ before the toxicity tests [15].

\section{Cytotoxicity assay}

Cytotoxicity was measured using the MTT assay. After $24 \mathrm{~h}$ stabilization, the cells were treated with $1 \mu \mathrm{g} / \mathrm{mL}, 5$ $\mu \mathrm{g} / \mathrm{mL}, 10 \mu \mathrm{g} / \mathrm{mL}$ and $25 \mu \mathrm{g} / \mathrm{mL}$ concentrations of PHMG for $24 \mathrm{~h}, 48 \mathrm{~h}, 72 \mathrm{~h}$ and $96 \mathrm{~h}$, respectively. After the exposure, 100 $\mu \mathrm{L}$ of MTT solution $(5 \mathrm{mg} / \mathrm{mL})$ was added, and the cells were incubated for $2 \mathrm{~h}$ at $37^{\circ} \mathrm{C}$. The cells were treated with $100 \mu \mathrm{L}$ of dimethyl sulfoxide to solubilize the purple formazan, and the absorbance was quantified in $570 \mathrm{~nm}$ using the microplate spectrophotometer system (VersaMax, Molecular Devices, Sunnyvale, CA, USA) [15].

\section{Gene expression}

The cells were incubated with PHMG for $24 \mathrm{~h}$ at concentrations of $1 \mu \mathrm{g} / \mathrm{mL}, 5 \mu \mathrm{g} / \mathrm{mL}, 10 \mu \mathrm{g} / \mathrm{mL}$ and $25 \mu \mathrm{g} / \mathrm{mL}$. Total RNA was prepared using RiboEx ${ }^{\mathrm{TM}}$ (GeneAlls. Seoul, Korea) according to the manufacturer's instruction. Reverse transcription - polymerase chain reaction (RT-PCR) was performed with $1 \mu \mathrm{g}$ of total RNA, $1 \mu \mathrm{L}$ of 100 pmol oligo dT primer and reaction mixture (Bioneer, Daejeon, Korea) in a total volume of $20 \mu \mathrm{L}$ at $42{ }^{\circ} \mathrm{C}$ for $60 \mathrm{~min}$. Then PCR was performed for 25-30 cycles at $95{ }^{\circ} \mathrm{C}$ for $20 \mathrm{sec}, 55^{\circ} \mathrm{C}$ for $20 \mathrm{sec}$, and $72{ }^{\circ} \mathrm{C}$ for $30 \mathrm{sec}$. cDNA products were amplified using appropriate oligo-primers, applied on $1 \%$ agarose gel then separated through electrophoresis and the images were captured. Primer sequences of amplified genes are shown in Table 1. The partial gene of glyceraldehyde 3-phosphate dehydrogenase (GAPDH) was also amplified as a loading control $[15,16]$. 
Table 1 Primer sequences of genes used in this study.

\begin{tabular}{|c|c|}
\hline Primer name & Sequence \\
\hline TNF- $\alpha$ & $\begin{array}{l}\text { F, 5' - GGAGCTGCCTTGGTTCTCAC - 3' } \\
\text { R, } 5 \text { - ATGTAGCGACGGGTCAGTCA - } 3\end{array}$ \\
\hline TGF- $\beta$ & $\begin{array}{l}\text { F, 5' - CAGAGAAGAACTGCTGTGTGC - 3' } \\
\text { R, 5' - TGTCCAGGCTCCAGATGTAGG - 3' }\end{array}$ \\
\hline$\alpha-S M A$ & $\begin{array}{l}\text { F, 5' - ATTGTGCTATGTCGCTCTGG - 3' } \\
\text { R, 5' - GATGAAGGAGGGCTGGAA - 3' }\end{array}$ \\
\hline MMP-2 & $\begin{array}{l}\mathrm{F}, 5^{\prime} \text { - GCCCTGACCAAGGTTACAGC - 3' } \\
\text { R, 5' - CCTGTGACAGGCGGAAGTTC - 3' }\end{array}$ \\
\hline MMP-3 & $\begin{array}{l}\mathrm{F}, 5^{\prime} \text { - CAAGGGATGCAGACACCACC - 3' } \\
\text { R, 5' - GAGTCCAGCTTGCCTGTCAC - 3' }\end{array}$ \\
\hline MMP-9 & $\begin{array}{l}\mathrm{F}, 5^{\prime}-\text { AAGACGCAGACGGTGGATTC - 3' } \\
\text { R, 5'-ACTCACACGCCAGAAGAAGC - 3' }\end{array}$ \\
\hline TIMP-1 & $\begin{array}{l}\text { F, 5' - GAACGGGCTCTTGCACATCA - 3' } \\
\text { R, 5' - GAGCTGGTCTGTCCACAAGC - 3' }\end{array}$ \\
\hline TIMP-2 & $\begin{array}{l}\text { F, 5' - CTGTGTTTCCGTTGCCCTTG - 3' } \\
\text { R, 5' - AATTACGGCAGCAAGTCCGA - 3' }\end{array}$ \\
\hline TIMP-3 & $\begin{array}{l}\text { F, 5' - GCCTTCTGCAACTCCGACAT - 3' } \\
\text { R, 5' - GTGGCGTTGATGGTCGTCTT - 3' }\end{array}$ \\
\hline $\mathrm{HO}-1$ & $\begin{array}{l}\text { F, 5' - CAGCTTGCCCCAGGATTTGT - 3' } \\
\text { R, 5' - TACAGGGAGGCCATCACCAG - 3' }\end{array}$ \\
\hline COX-2 & $\begin{array}{l}\text { F, 5' - TTTGGTCTGGTGCCTGGTTT - 3' } \\
\text { R, 5' - CATCTGCCTGCTCTGGTCAA - 3' }\end{array}$ \\
\hline GAPDH & $\begin{array}{l}\text { F, 5' - AGACGGCGTCTGTAGAAGCT - 3' } \\
\text { R, 5' - GGGCCAAGTCCCACTATTGC - 3' }\end{array}$ \\
\hline
\end{tabular}

\section{Western blot}

SIRC cells were seeded in numbers of $5 \times 10^{5}$ cells $/ \mathrm{mL}$ in each well of 6-well plate and cultured for $24 \mathrm{~h}$. After rinsing the cultured cells with a fresh medium, PHMG was added at concentrations of $1 \mu \mathrm{g} / \mathrm{mL}, 5 \mu \mathrm{g} / \mathrm{mL}, 10 \mu \mathrm{g} / \mathrm{mL}$ and 25 $\mu \mathrm{g} / \mathrm{mL}$. Following a $24 \mathrm{~h}$ incubation, cells were lysed using a lysis buffer containing sodium dodecyl sulfate (SDS) buffer and protease inhibitor. The cell lysates were collected and centrifuged at 14,000 $\mathrm{g}$ for $15 \mathrm{~min}$. Equal amounts of proteins assayed by BCA protein assay kit (Thermo Scientific, MA, USA) were applied on SDS-polyacrylamide gel electrophoresis (PAGE) and the samples were transferred to nitrocellulose membranes. The membranes were incubated with $5 \%$ non-fat milk in a mixture buffer of tris-buffered saline and Tween 20 (TBST buffer) for $2 \mathrm{~h}$. Anti-rabbit antibody for $\alpha$-SMA, HO-1, TGF- $\beta$, COX-2, MMPs, TIMPs, and $\beta$-actin (Abcam, Cambridge, UK) was incubated overnight at room temperature with shaking. After washing the membranes, they were incubated with goat polyclonal secondary antibody conjugated with horseradish peroxidase (Abcam, Cambridge, UK). The membranes were visualized using chemiluminescent western blotting detection reagents (Bio-Rad, CA, USA) and all the bands were obtained using an image software (Chemidoc-IT ${ }^{2}$ imager, UVP, CA, USA) [16].

\section{Reactive oxygen species (ROS) evaluation}

Cells were grown to confluence in a 12 well-plate at $24 \mathrm{~h}$ after seeding $\left(5 \times 10^{5}\right.$ cells/well), were treated with PHMG at the concentration of $1 \mu \mathrm{g} / \mathrm{mL}, 5 \mu \mathrm{g} / \mathrm{mL}, 10 \mu \mathrm{g} / \mathrm{mL}$, and $25 \mu \mathrm{g} / \mathrm{mL}$, and further incubated with $40 \mu \mathrm{M}$ of $\mathrm{H}_{2} \mathrm{DCFDA}$ (Invitrogen, CA, USA) for $1 \mathrm{~h}$. At the end of $\mathrm{H}_{2}$ DCFDA incubation, cells were washed with phosphate-buffered saline (PBS), and were visualized with a fluorescent microscope (Nikon, Tokyo, Japan) [14].

\section{Results}

Cytotoxicity

SIRC cells were incubated with PHMG at concentrations of $1 \mu \mathrm{g} / \mathrm{mL}, 5 \mu \mathrm{g} / \mathrm{mL}, 10 \mu \mathrm{g} / \mathrm{mL}$, and $25 \mu \mathrm{g} / \mathrm{mL}$ for $24 \mathrm{~h}$, 48 h, 72 h, and 96 h, respectively, and viability was determined. As shown in Figure 1, cell viability decreased in PHMGtreated groups in all the test concentrations in a time and concentration-dependent manner. At a low concentration of 1 $\mu \mathrm{g} / \mathrm{mL}$, no cytotoxicity was observed in the $24 \mathrm{~h}$-treatment group but appeared after $48 \mathrm{~h}$-exposure. When the concentration 
of PHMG was increased to $5 \mu \mathrm{g} / \mathrm{mL}$, cytotoxicity was observed after 24 h-exposure and further increased with increased exposure time. The IC 50 values obtained when SIRC cells were incubated with PHMG for $24 \mathrm{~h}, 48 \mathrm{~h}, 72 \mathrm{~h}$, and $96 \mathrm{~h}$ were, $20.8 \mu \mathrm{g} / \mathrm{mL}, 13.8 \mu \mathrm{g} / \mathrm{mL}, 8.5 \mu \mathrm{g} / \mathrm{mL}$, and $6.2 \mu \mathrm{g} / \mathrm{mL}$, respectively.

\section{Induction of inflammation related genes}

To investigate the expression level of mRNA in cultured SIRC cells, RT-PCR was performed. As shown in Figure 2, cyclooxygenase-2 (COX-2) and hemeoxygenase-1 (HO-1) were induced by PHMG. COX-2, a cyclooxygenase enzyme, catalyzes a key step in the conversion of arachidonic acid to prostaglandin $\mathrm{H}_{2}$, the immediate substrate for a series of cellspecific prostaglandin and thromboxane synthases. It is expressed in its inducible form in response to inflammatory stimuli; this is why all conventional nonsteroidal anti-inflammatory drugs inhibit the expression of COX-2. As shown in Figure 2, the COX-2 gene was only induced in the highest concentration of PHMG $(25 \mu \mathrm{g} / \mathrm{mL})$. However, the HO- 1 which is an oxidative stress marker and induced by a variety of chemicals was induced by all the PHMG concentrations (from $1 \mu \mathrm{g} / \mathrm{mL}$ to $25 \mu \mathrm{g} / \mathrm{mL}$ ).

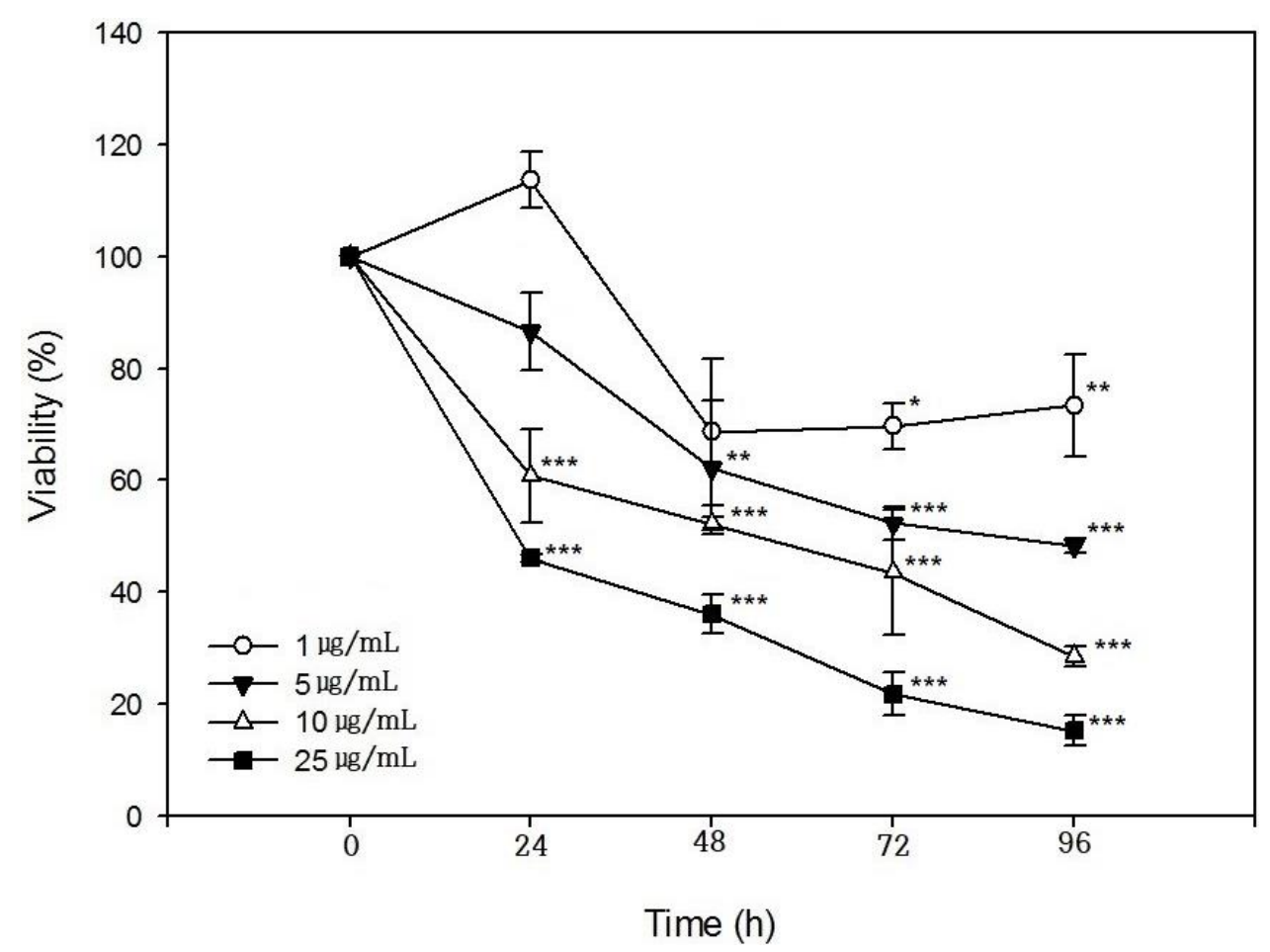

Figure 1 Effects of polyhexamethylene guanidine (PHMG) on the viability of cultured Statens Seruminstitut Rabbit Cornea (SIRC) cells. Cell viability was assessed by 3-(4,5-dimethylthiazol-2-yl)-2, 5-diphenyltetrazolium bromide (MTT) assays, and the results are presented as a percentage of control group viability. Cells were treated with indicated concentrations $(1 \mu \mathrm{g} / \mathrm{mL}, 5 \mu \mathrm{g} / \mathrm{mL}, 10 \mu \mathrm{g} / \mathrm{mL}$, and $25 \mu \mathrm{g} / \mathrm{mL})$ for $24 \mathrm{~h}, 48 \mathrm{~h}, 72 \mathrm{~h}$, and $96 \mathrm{~h}$. Results represent the means of three separate experiments, and error bars represent the standard error of the mean. Data were analyzed by one-way ANOVA (analysis of variance) with post-hoc Turkey test. ${ }^{*}: \mathrm{P}<0.05 ;{ }^{* *}: \mathrm{P}<0.01$; ***: $\mathrm{P}<0.001$. 


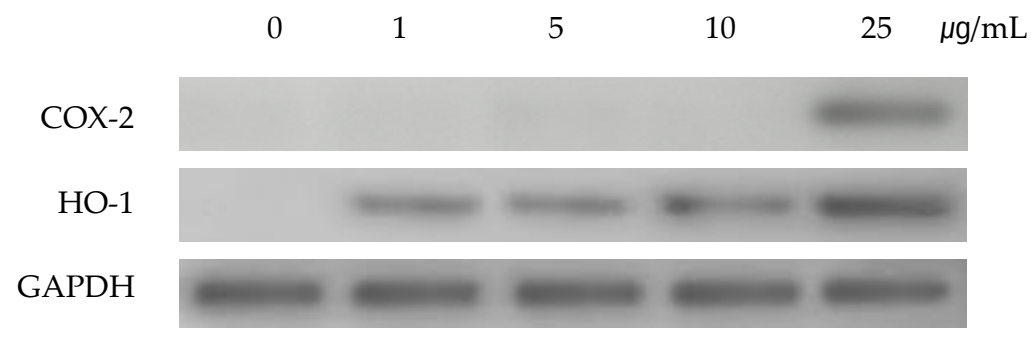

Figure 2 Effects of polyhexamethylene guanidine (PHMG) on the gene expressions of cyclooxygenase-2 (COX-2) and heme oxygenase-1 (HO-1) in cultured Statens Seruminstitut Rabbit Cornea (SIRC) cells. Gene expressions of COX-2 and HO-1 in cultured SIRC cells treated with PHMG were analyzed. Cells were treated with concentrations of $1 \mu \mathrm{g} / \mathrm{mL}, 5 \mu \mathrm{g} / \mathrm{mL}, 10 \mu \mathrm{g} / \mathrm{mL}$, and $25 \mu \mathrm{g} / \mathrm{mL}$ for $24 \mathrm{~h}$. mRNA transcription was determined by reverse transcription - polymerase chain reaction (RT-PCR) analysis using respective primers described in Table 1. Results were confirmed by three separate experiments, and representative images are shown. Glyceraldehyde3-phosphate dehydrogenase (GAPDH) was used as a housekeeping gene during the comparison of gene expression data.

\section{Reactive oxygen species (ROS) generation}

Images of ROS production in cultured PHMG-treated SIRC cells at $1 \mu \mathrm{g} / \mathrm{mL}, 5 \mu \mathrm{g} / \mathrm{mL}, 10 \mu \mathrm{g} / \mathrm{mL}$, and $25 \mu \mathrm{g} / \mathrm{mL}$ for $24 \mathrm{~h}$ were obtained using a fluorescent microscope through $\mathrm{H}_{2}$ DCFDA method. Significant evidence of ROS generation in PHMG-treated SIRC cells is shown in Figure 3. In the highest concentration of PHMG $(25 \mu \mathrm{g} / \mathrm{mL})$, most of the cells were detached from the bottom of the plate because of cytotoxicity, and the fluorescence emission, a confirmation of ROS generation, was higher than in the other treated groups. Notably, the ROS generation positively correlated with the induction of the HO-1 gene.

\section{Changes in fibrosis-related biomarkers}

As shown in Figure 4, the gene of TNF- $\alpha$ was induced at PHMG concentration of $10 \mu \mathrm{g} / \mathrm{mL}$ and $25 \mu \mathrm{g} / \mathrm{mL}$. TNF$\alpha$, a pleiotropic cytokine, triggers multiple signaling pathways involved in inflammation, proliferation, apoptosis, and fibrosis. TGF- $\beta$ which is also associated with the signaling of fibrosis by modulating the MMPs and TIMPs, was also induced by PHMG treatment in SIRC cells. Tissue inhibitors of matrix metalloproteinases (TIMP-1, TIMP-2 and TIMP-3), were all induced at all the PHMG concentrations (from $1 \mu \mathrm{g} / \mathrm{mL}$ to $25 \mu \mathrm{g} / \mathrm{mL}$ ). The induction of TIMPs is associated with a significant reduction in the matrix degradation capacity. Gene expression of MMPs, which are proteinases that degrade ECM, varied with subtypes; MMP-2 and MMP-3 were induced but MMP-9 was suppressed by PHMG treatment. The gene of $\alpha$-SMA which is activated by TGF- $\beta$ and associated with fibrosis was also induced by PHMG in cultured SIRC cells. The protein levels assayed by immunoblotting positively correlated with the changes of gene expressions. As shown in Figure 5, the protein level of $\alpha$-SMA was significantly increased in a concentration-dependent manner. 

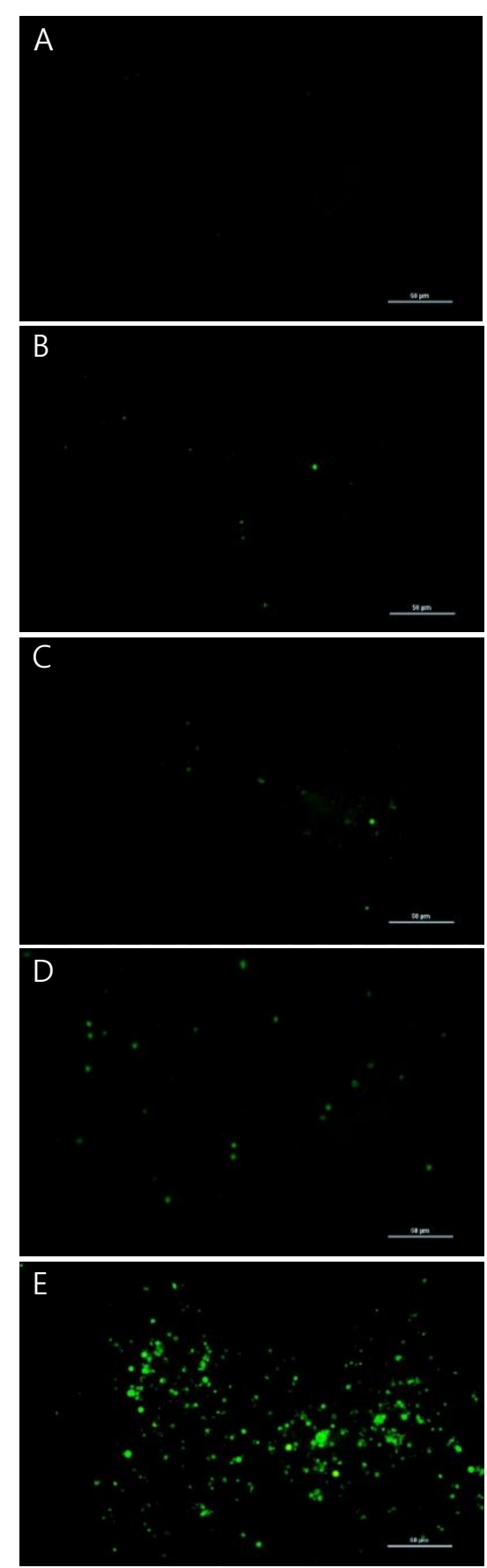

Figure 3 Effects of polyhexamethylene guanidine(PHMG) on ROS induction in cultured Statens Seruminstitut Rabbit Cornea (SIRC) cells. Cells were treated with PHMG $(1 \mu \mathrm{g} / \mathrm{mL}, 5 \mu \mathrm{g} / \mathrm{mL}, 10 \mu \mathrm{g} / \mathrm{mL}$, and $25 \mu \mathrm{g} / \mathrm{mL})$ for 24 $\mathrm{h}$, and then $2^{\prime}, 7^{\prime}$-dichlorodihydrofluorescein diacetate ( $\left.\mathrm{H}_{2} \mathrm{DCFDA}\right)$ was added to cells. SIRC cells were visualized with a fluorescent microscope (x200), the representative images are shown. A) fluorescent microscope image of non-treated control group; B) $1 \mu \mathrm{g} / \mathrm{mL}$; C) $5 \mu \mathrm{g} / \mathrm{mL}$; D) $10 \mu \mathrm{g} / \mathrm{mL}$; F) $25 \mu \mathrm{g} / \mathrm{mL}$. Scale bar in figures represent 50 $\mu \mathrm{m}$. 


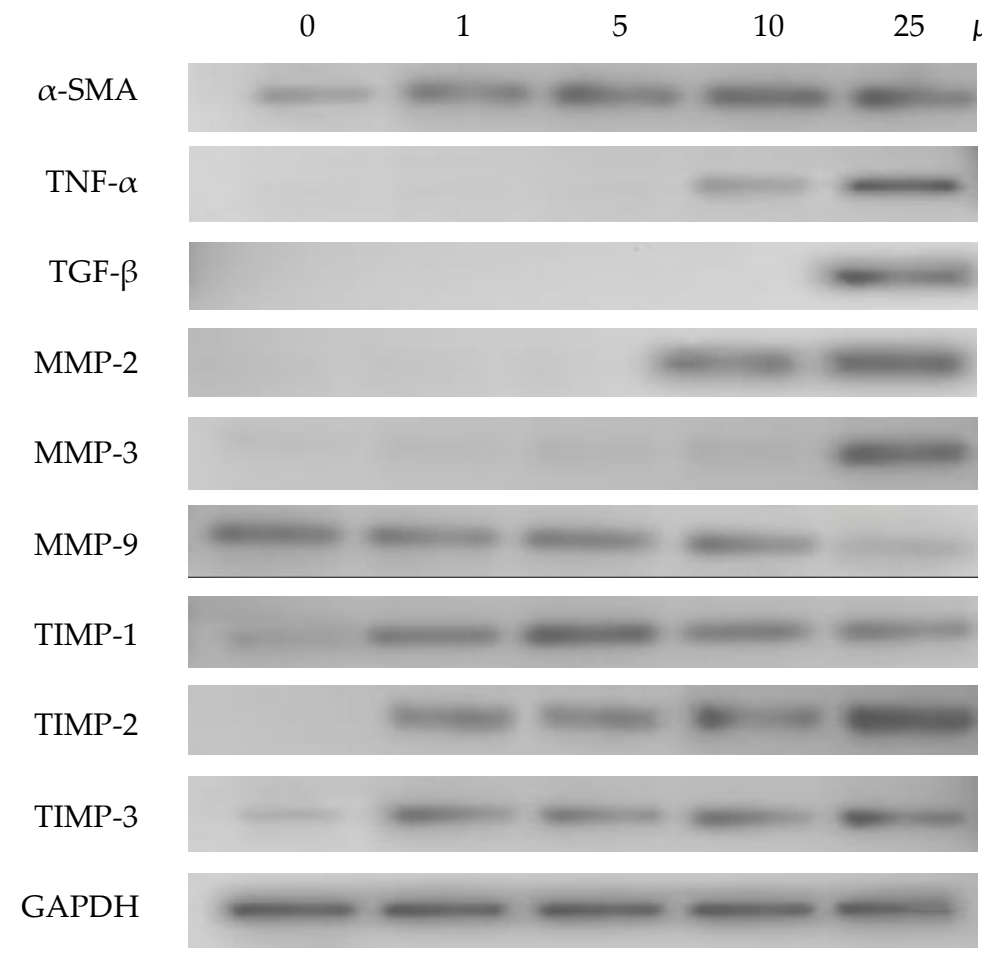

Figure 4 Effects of polyhexamethylene guanidine(PHMG) on the expressions of fibrosis-related genes in cultured Statens Seruminstitut Rabbit Cornea (SIRC) cells. Gene expressions of $\alpha$-SMA, TNF- $\alpha$, TGF- $\beta$, MMPs, and TIMPs in cultured SIRC cells treated with PHMG were analyzed. Cells were treated with concentrations of $1 \mu \mathrm{g} / \mathrm{mL}, 5$ $\mu \mathrm{g} / \mathrm{mL}, 10 \mu \mathrm{g} / \mathrm{mL}$, and $25 \mu \mathrm{g} / \mathrm{mL}$ for $24 \mathrm{~h}$. mRNA transcription was determined by reverse transcription polymerase chain reaction (RT-PCR) analysis using respective primers described in Table 1. Results were confirmed by three separate experiments and the representative images are shown. Glyceraldehyde-3-phosphate dehydrogenase (GAPDH) was used as a housekeeping gene during the comparison of gene expression data.

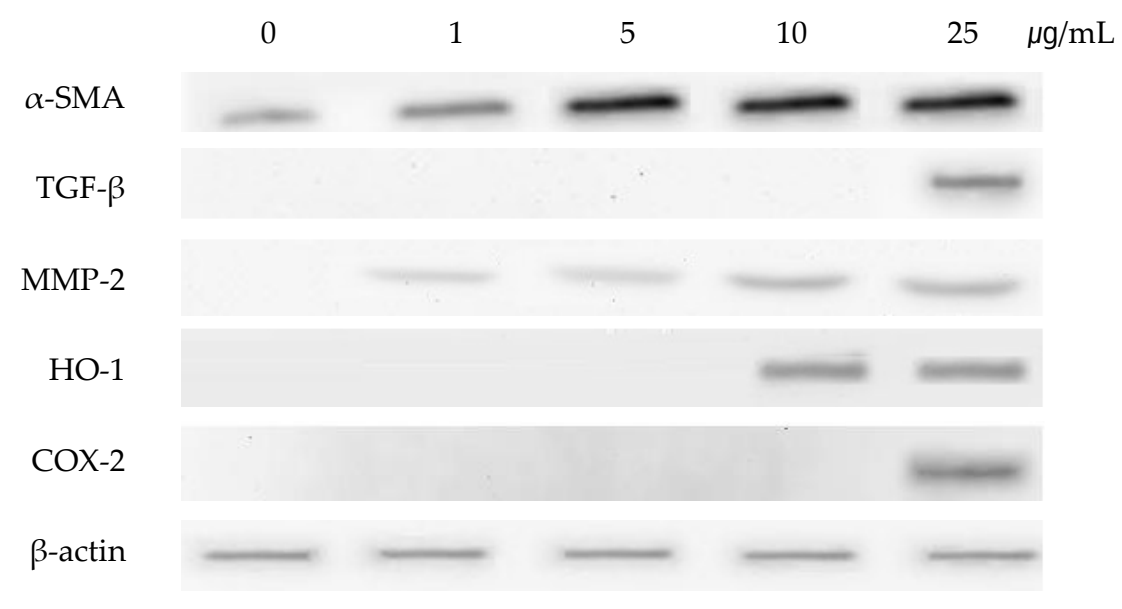

Figure 5 Effects of polyhexamethylene guanidine (PHMG) on the expression of fibrosis-related proteins in cultured Statens Seruminstitut Rabbit Cornea (SIRC) cells. Western blot analysis was performed to evaluate the expression of fibrosis-related proteins $\alpha$-SMA, TGF- $\beta$, and MMP-2. Levels of hemooxygense- 1 (HO-1) and cyclooxygenase-2 (COX-2) were also evaluated. Results were confirmed by three separate experiments and representative images are shown. $\beta$-actin level was analyzed for the comparisons of protein expression data. 


\section{Discussion}

Fibrosis is a pathological wound healing in which connective tissue replaces normal parenchymal tissues, and is characterized by the accumulation of ECM macromolecules such as collagen, elastin, and fibronectin. Previous studies have reported the association of fibrosis with renin-angiotensin system, inflammation and oxidative stress, and TGF- $\beta /$ Smad signaling. Among them, the TGF $\beta /$ Smad signaling plays the most important role in the process of fibrosis in many organs including the lungs, liver, heart and kidneys $[17,18]$. The signaling pathway is now known to be an effective target of antifibrotic therapy. Polysaccharides from Ephedra sinica Stapt downregulated the production of TGF- $\beta 1$ and p-Smad2/3 and reduced pulmonary inflammation [19]. Phenylethanol glycoside from Cistanche tubulosa could block the conduction of the signaling pathway in TGF $\beta /$ Smad signaling and are potential anti-fibrosis screening agents [20]. A major process of fibrosis is the differentiation of fibroblastic cells into myofibroblasts that express $\alpha$-SMA. Since myofibroblasts are virtually absent in normal organs, their presence is a marker of fibrosis pathogenesis and they are largely responsible for the accumulation of ECM. In the signaling pathway of TGF- $\beta / S m a d$, Smad 2 and Smad 3 are phosphorylated by TGF $\beta 1$-receptor-type I and then, they activate the differentiation of fibroblasts into myofibroblasts [21]. TNF- $\alpha$ is a potent pro-inflammatory cytokine and inhibits the activity of TGF- $\beta$ in ECM production, such as type I collagen and elastin, and inhibits TGF- $\beta$ signaling by inhibiting Smad signaling through AP-1 activation [22]. Degradation of ECM, as mediated by MMPs and antagonized by TIMPs, is critical for embryonic development and adult tissue homeostasis. MMPs and TIMPs are regulated by TNF- $\alpha$ and TGF- $\beta$. Some of MMPs are induced by TNF- $\alpha$ and some TIMPs are induced by TGF- $\beta$, which determines the accumulation of ECM molecules. This means that the functional antagonisms of the cytokines may be a useful tool in investigating the complex cellular signals that regulate ECM formation [23].

Myofibroblasts are a differentiated cell type essential for wound healing and tissue remodeling after cell damage. Myofibroblasts are typically activated-fibroblasts and they can also be derived from other types of cells such as epithelial cells, endothelial cells and mononuclear cells. Epithelial-mesenchymal transition (EMT) in which the epithelial changes its phenotype to a myofibroblast, is observed in the process of interstitial renal fibrosis (renal tubular epithelial cells) [24], pulmonary fibrosis (type II alveolar epithelial cells) [25], liver fibrosis [26], or in specific ocular tissues [27]. TGF- $\beta$ is expressed in corneal tissues or in an injured cornea, and in infiltrating inflammatory cells in the eyes, and it plays an important role in the development of scars on the ocular surface.

As shown in Figure 1, the viability of cultured SIRC cells was decreased by PHMG in a concentration- and timedependent manner. The IC 50 values obtained at $24 \mathrm{~h}, 48 \mathrm{~h}, 72 \mathrm{~h}$, and $96 \mathrm{~h}$ of exposure to PHMG were in the same range as those previously reported in HepG2, A549, BEAS-2B, and THP-1 cells [16]. The IC 50 values obtained at $24 \mathrm{~h}, 48 \mathrm{~h}, 72 \mathrm{~h}$, and $96 \mathrm{~h}$ of SIRC cells incubation with PHMG were $20.8 \mu \mathrm{g} / \mathrm{mL}, 13.8 \mu \mathrm{g} / \mathrm{mL}, 8.5 \mu \mathrm{g} / \mathrm{mL}$, and $6.2 \mu \mathrm{g} / \mathrm{mL}$, respectively and 7.6 $\mu \mathrm{g} / \mathrm{mL}, 5.8 \mu \mathrm{g} / \mathrm{mL}$, and $5.8 \mu \mathrm{g} / \mathrm{mL}$ at $24 \mathrm{~h}, 48 \mathrm{~h}$ and $72 \mathrm{~h}$, respectively in HepG2 cells. Although the susceptibility is different from cells to cells, the viability patterns after PHMG exposure is similar. The slight difference in the IC 50 values could have resulted from the different assay methods of cell viability, e.g. MTT assay, lactate dehydrogenase (LDH) activity assay, and WST-1 assay. The induction of the COX-2 gene by PHMG indicates inflammatory responses in the cells. The inflammatory response could have been initiated by ROS generated in response to PHMG exposure and the induction of HO- 1 gene indicated the possibility PHMG toxicity in the cultured SIRC cells as shown in Figure 2. Reactive oxygen species generation after exposure to PHMG was previously reported in other studies [28,29]. Reactive oxygen species were generated in cultured lung epithelia cells treated with PHMG for $6 \mathrm{~h}$ at $0.5 \mu \mathrm{g} / \mathrm{mL} \sim 4 \mu \mathrm{g} / \mathrm{mL}$ and the ROS was associated with inducing DNA damage. In the present study, similar results were also observed in SIRC cells as shown in Figure 3. The fluorescent images were intensified with an increased concentration of PHMG.

Extracellular matrix degradation, a process that determines organ remodeling, depends on the balance between MMPs and TIMPs. MMPs are an endogenous family of enzymes that degrade ECM proteins and consist of more than 20 unique proteins; MMP-2 and MMP-9 have gelatinase activity and MMP-3 has stromelysins activity. TNF- $\alpha$ activates MMPs, and TGF- $\beta$ inhibits them. The role of TIMPs is to prevent excessive ECM degradation by MMPs. There are four types of TIMPs, TIMP-1, $-2,-3$, and -4 which act as natural inhibitors of active forms of all MMPs through binding to MMPs in a 1:1 ratio. So, the balance of MMPs and TIMPs is very important in ECM remodeling [30]. TNF- $\alpha$ and TGF- $\beta$ are the most important cytokines in the process of fibrosis and they antagonize each other. While TNF- $\alpha$ activates MMPs, TGF- $\beta$ activates TIMPs which in turn inactivate MMPs $[30,31]$. In the present study, gene expressions of TNF- $\alpha$ and TGF- $\beta$ were induced in cultured SIRC cells treated with PHMG for $24 \mathrm{~h}$. The induction of cytokines, TNF- $\alpha$ and TGF- $\beta$, regulated the gene expressions of MMPs and TIMPs. TIMP-1, -2, and -3 were all induced in PHMG-treated SIRC cells. On the other hand, gene expression of MMP-9 was suppressed while those of MMP-2 and MMP-3 were increased by PHMG (Figure 4). The regulation of MMPs and TIMPs in ECM remodeling is very complex and not fully elucidated yet. Furthermore, the induction/suppression of MMPs and TIMPs by TNF- $\alpha$ and TGF- $\beta$ seems to vary with exposure time and concentration of the cytokines [32,33]. However, the induction of $\alpha$-SMA is critical; it determines the final ECM remodeling outcomes. In this study, the gene expression and protein levels of $\alpha$-SMA were significantly increased by PHMG in cultured SIRC cells as shown in Figures 4 and 5. 


\section{Conclusions}

As eyes are one of the direct target organs like lung and skin to HDs, they are very vulnerable to the chemicals. Based on the results, exposure to PHMG may cause fibrosis in cultured rabbit corneal cells through the induction of TNF$\alpha$, TGF- $\beta$, and the related process of fibrosis signaling. Human beings exposed to the humidifier disinfectant are known to suffer from the eye-related disease including conjunctivitis. From this, it seems that detailed investigation and monitoring of patients on eye disease including fibrosis will be necessary.

\section{Acknowledgement}

This study was supported by the Korea Ministry of Environment (MOE) through the environmental health action program (2017001360001).

\section{Conflict of interest}

The authors have no conflicts of interest associated with this study.

\section{CRediT author statement}

HL: Methodology, Review of articles, Resource, Investigation, Writing-Original draft preparation; JP: Methodology, Resources, Validation, Formal analysis; KP: Review of articles, Supervision, Writing-Review \& Editing, Project administration

\section{ORCID}

Kwangsik Park: 0000-0001-9346-2244

\section{References}

[1] Paek D, Koh Y, Park DU, Cheong HK, Do KH, Lim CM, et al. Nationwide study of humidifier disinfectant lung injury in South Korea, 1994-2011. Incidence and dose-response relationships. Ann Am Thorac Soc 2015;12(12):1813-1821.

[2] Park DU, Ryu SH, Lim HK, Kim SK, Choi YY, Ahn JJ, et al. Types of household humidifier disinfectant and associated risk of lung injury (HDLI) in South Korea. Sci Total Environ 2017;596-597:53-60.

[3] Park K. An analysis of a humidifier disinfectant case from a toxicological perspective. Environ Health Toxicol 2016;31:e2016013.

[4] Leem JH, Kim HJ, Cheong HK, Lee KM, Lee JH, Park KS, et al. Final report: selection and diagnostic criteria for non-lung diseases according to the use of humidifier disinfectant. Seoul: Korean Society of Environmental Health and Toxicology $2017 ; 13-83$

[5] Leem JH, Lee JH. Humidifier disinfectant-associated specific diseases should be called together as "humidifier disinfectant syndrome". Environ Health Toxicol 2017;32:e2017017.

[6] Cho HJ, Lee SY, Park D, Ryu SH, Yoon J, Jung S, et al. Early-life exposure to humidifier disinfectant determines the prognosis of lung function in children. BMC Pulm Med 2019;19(1):261.

[7] Park DU, Park J, Yang KW, Park JH, Kwon JH, Oh HD. Properties of polyhexamethylene guanidine (PHMG) associated with fatal lung injury in Korea. Molecules 2020;25(14):3301.

[8] Kim HR, Hwang GW, Naganuma A, Chung KH. Adverse health effects of humidifier disinfectants in Korea: lung toxicity of polyhexamethylene guanidine phosphate. J Toxicol Sci. 2016;41(6):711-717.

[9] Lee SJ, Park JH, Lee JY, Jeong YJ, Song JA, Lee K, et al. Establishment of a mouse model for pulmonary inflammation and fibrosis by intratracheal instillation of polyhexamethyleneguanidine phosphate. J Toxicol Pathol 2016;29(2):95-102.

[10] Kim MS, Kim SH, Jeon D, Kim HY, Lee K. Changes in expression of cytokines in polyhexamethylene guanidine-induced lung fibrosis in mice: Comparison of bleomycin-induced lung fibrosis. Toxicology 2018;393:185-192.

[11] Song J, Kim W, Kim YB, Kim B, Lee K. Time-course of polyhexamethyleneguanidine phosphate-induced lung inflammation and fibrosis in mice. Toxicol Appl Pharmacol 2018;345:94-102. 
[12] Zhu X, Kong X, Ma S, Liu R, Li X, Gao S, et al. TGF $\beta /$ Smad mediated the polyhexamethyleneguanide areosol-induced irreversible pulmonary fibrosis in subchronic inhalation exposure. Inhal Toxicol 2020;32(11-12):419-430.

[13] Kim HR, Lee K, Park CW, Song JA, Shin DY, Park YJ, et al. Polyhexamethylene guanidine phosphate aerosol particles induce pulmonary inflammatory and fibrotic responses. Arch Toxicol 2016;90(3):617-632.

[14] Park J, Lee H, Park K. Eye irritation tests of polyhexamethylene guanidine phosphate (PHMG) and chloromethylisothiazolinone/methylisothiazolinone (CMIT/MIT) using a tissue model of reconstructed human cornealike epithelium. Environ Health Toxicol 2019;34(2):e2019004.

[15] Lee H, Park K. In vitro cytotoxicity of zinc oxide nanoparticles in cultured Statens Seruminstitut Rabbit Cornea cells. Toxicol Res 2019;35(3):287-294.

[16] Kim SH, Kwon D, Lee S, Ki SH, Jeong HG, Hong JT, et al. Polyhexamethyleneguanidine Phosphate-induced cytotoxicity in liver cells is alleviated by Tauroursodeoxycholic Acid (TUDCA) via a reduction in endoplasmic reticulum stress. Cells 2019;8(9):1023.

[17] Rockey DC, Bell PD, Hill JA. Fibrosis--A Common Pathway to Organ Injury and Failure. New Engl J Med 2015;372(12):1138-1149

[18] Hu HH, Chen DQ, Wang YN, Feng YL, Cao G, Vaziri ND, et al. New insights into TGF- $\beta /$ Smad signaling in tissue fibrosis. Chem Biol Interact 2018;292:76-83.

[19] Liang S, Meng X, Wang Z, Liu J, Kuang H, Wang Q. Polysaccharide from Ephedra sinica Stapf inhibits inflammation expression by regulating Factor- $\beta 1 / S m a d 2$ signaling. Int J Biol Macromol 2018;106:947-954.

[20] You SP, Ma L, Zhao J, Zhang SL, Liu T. Phenylethanol glycosides from Cistanche tubulosa suppress hepatic stellate cell activation and block the conduction of signaling pathways in TGF- $\beta 1 /$ smad as potential anti-hepatic fibrosis agents. Molecules 2016;21(1):102.

[21] Gu L, Zhu YJ, Yang X, Guo ZJ, Xu WB, Tian XL. Effect of TGF-beta/Smad signaling pathway on lung myofibroblast differentiation. Acta Pharmacol Sin 2007;28(3):382-391.

[22] Yamane K, Ihn H, Asano Y, Jinnin M, Tamaki K. Antagonistic effects of TNF-alpha on TGF-beta signaling through down-regulation of TGF-beta receptor type II in human dermal fibroblasts. J Immunol 2003;171(7):3855-3862.

[23] Zhou L, Yan C, Gieling RG, Kida Y, Garner W, Li W, et al. Tumor necrosis factor-alpha induced expression of matrix metalloproteinase-9 through p21-activated kinase-1. BMC Immunol 2009;10(1):1-15.

[24] Sato M, Muragaki Y, Saika S, Roberts AB, Ooshima A. Targeted disruption of TGF-beta1/Smad3 signaling protects against renal tubulointerstitial fibrosis induced by unilateral ureteral obstruction. J Clin Invest 2003;112(10):1486-1494.

[25] Willis BC, duBois RM, Borok Z. Epithelial origin of myofibroblasts during fibrosis in the lung. Proc Am Thorac Soc 2006;3(4):377-382.

[26] Kaimori A, Potter J, Kaimori JY, Wang C, Mezey E, Koteish A. Transforming growth factor-beta1 induces an epithelialto-mesenchymal transition state in mouse hepatocytes in vitro. J Biol Chem 2007;282(30):22089-22101.

[27] Saika S, Shirai K, Yamanaka O, Miyazaki KI, Okada Y, Kitano A, et al. Loss of osteopontin perturbs the epithelialmesenchymal transition in an injured mouse lens epithelium. Lab Invest 2007;87(2):130-138.

[28] Park JS, Park YJ, Kim HR, Chung KH. Polyhexamethylene guanidine phosphate-induced ROS-mediated DNA damage caused cell cycle arrest and apoptosis in lung epithelial cells. J Toxicol Sci 2019;44(6):415-424.

[29] Song J, Jung KJ, Yoon SJ, Lee K, Kim B. Polyhexamethyleneguanidine phosphate induces cytotoxicity through disruption of membrane integrity. Toxicology 2019;414:35-44.

[30] Kwak HB. Aging, exercise, and extracellular matrix in the heart. J Exerc Rehabil 2013;9(3):338-347.

[31] Leivonen SK, Lazaridis K, Decock J, Chantry A, Edwards DR, Kähäri VM. TGF- $\beta$-elicited induction of tissue inhibitor of metalloproteinases (TIMP)-3 expression in fibroblasts involves complex interplay between Smad3, p38 $\alpha$, and ERK1/2. PLoS One 2013;8(2):e57474 
[32] Zhong L, Zheng J, Sun Q, Wei K, Hu Y. Radix Tetrastigma hemsleyani flavone inhibits proliferation, migration, and invasion of human lung carcinoma A549 cells. Onco Targets Ther 2016;9:635-641.

[33] Gong JH, Cho IH, Shin D, Han SY, Park SH, Kang YH. Inhibition of airway epithelial-to-mesenchymal transition and fibrosis by kaempferol in endotoxin-induced epithelial cells and ovalbumin-sensitized mice. Lab Invest 2014;94(3):297308. 